\title{
Assessment of hand dysfunction in patients receiving hemodialysis through arteriovenous fistula
}

\author{
Arteriovenöz fistül aracılı hemodiyaliz yapılan hastalarda el disfonksiyonunun \\ değerlendirilmesi
}

Zeynep Tuna ${ }^{1}$, Deran Oskay ${ }^{1}$, Dilan Önder ${ }^{1}$, Salih İnal ${ }^{2}$

\begin{abstract}
Objective: Patients receiving haemodialysis treatment generally tend to avoid using the upper extremity with arteriovenous (AV) fistulae and it results in impairment of hand functions. Limited data are available about impairment associated with hand complications in those patients The aim of this pilot study is to evaluate the handgrip and pinching strengths and functional level of both hands in patients receiving haemodialysis.
\end{abstract}

Methods: Fifteen chronic renal failure patients receiving haemodialysis (30-83 years) and 11 age-matched healthy volunteers participated in the study. All the patients were undergoing treatment through arteriovenous fistulae in the upper extremity. Handgrip strength with a manual dynamometer and pinch strength with a pinchmeter were measured. Functional level of both hands was evaluated with Nine-Hole Peg Test.

Results: Handgrip strengths of both hands were lower in patients receiving haemodialysis than healthy control group $(p<0.01)$. Lateral, bipod and tripod pinching strengths were also lower in patients $(p<0.05)$ with excepting right hand lateral pinching $(p>0.05)$. 9-Hole Peg Test results in both placement and removal showed a great significant difference in both hands with a statistical significance of $p<0.001$.

Conclusion: Our first results revealed that chronic renal failure patients receiving haemodialysis treatment through arteriovenous fistulae in the upper extremity have a significant impairment in strength and functional level of hand. The lack of differences between two hands may be concluded that the upper extremity impairment in patients results from the disease course or haemodialysis treatment, not from the vascular access. J Clin Exp Invest 2015; 6 (2): 110-114

Key words: Arteriovenous fistula, dexterity, haemodialysis, hand functions, vascular access

\section{ÖZET}

Amaç: Hemodiyaliz tedavisi alan hastalar genellikle arteriovenöz fistülün olduğu üst ekstremitelerini kullanmaktan kaçınırlar ve bu durum el fonksiyonlarının bozulmasıyla suçlanmaktadır. Bu hastalarda ele ait komplikasyonlara ilişkin bilgiler yetersizdir. Bu pilot çalışmanın amacı, hemodiyaliz tedavisi alan hastalarda her iki elin kavrama ve çimdikleyici kuvvetlerini ve böylece fonksiyonel durumunu incelemektir.

Yöntemler: Hemodiyaliz tedavisi alan 15 kronik böbrek yetmezliği hastası (30-83 yaş) ve aynı yaş ortalamasına sahip 11 sağlıklı kontrol çalışmaya katıldı. Hasta grubun tamamı hemodiyaliz tedavisini üst ekstremitede bulunan arterivenöz fistül aracılığıyla alan hastalardı. Kavrama kuvveti manuel dinamometreyle, çimdikleyici kuvvet pinchmetre ile ölçüldü. Her iki elin fonksiyonel durumu Dokuz Delikli Peg Test ile değerlendirildi.

Bulgular: Hemodiyaliz tedavisi gören hastalarda her iki elin kavrama kuvvetleri sağlıklı kontrol grubundan daha zayıf bulundu $(p<0.01)$. Lateral, bipod ve tripod çimdikleyici kuvvetleri, sağ elin lateral kavraması $(p>0.05)$ hariç hasta grubunda daha zayıftı $(p<0.05)$. Dokuz Delikli Peg Testi takma ve çıkarma süreleri açısından her iki el arasında istatistiksel olarak belirgin derecede fark bulundu $(p<0.001)$.

Sonuç: Çalışmamızın ilk sonuçlarına göre, üst ekstremitede arteriovenöz fistül aracılığıyla hemodiyaliz tedavisi alan kronik böbrek yetmezliği hastalarının kavrama kuvveti ve fonksiyonel durumları kötü bulunmuştur. Ancak hasta grupta iki el arasında fonksiyonel anlamda bir fark olmaması, üst ekstremite disfonksiyonunun fistülden değil, hastalık süreci veya hemodiyaliz tedavisinden kaynaklanıyor olabileceğini göstermektedir.

Anahtar kelimeler: El fonksiyonları, hemodiyaliz, damar yolu, el becerisi, arteriovenöz fistül

${ }^{1}$ Gazi University Faculty of Health Sciences Department of Physiotherapy and Rehabilitation, Beşevler, Ankara, Turkey

${ }^{2}$ Süleyman Demirel University Hospital Department of Internal Medicine Division of Nephrology, Isparta, Turkey

Correspondence: Zeynep Tuna,

Gazi University Faculty of Health Sciences Department of Physiotherapy and Rehabilitation Beşevler, Ankara, Turkey Email: zeyneptuna6@yahoo.com 


\section{INTRODUCTION}

Insufficient daily life activities are among the factors affecting the general independence level of the individual. Ability to carry out the daily life activities depends on the entire body structures, predominantly the upper extremities. Dysfunction observed due to various reasons in extremities limit the independence levels of the individual, and as a result, this may affect the quality of life.

Renal replacement treatments for patients with end stage renal disease (ESRD) comprise haemodialysis (HD), peritoneal dialysis, or renal transplantation. The HD method that has been practiced especially since 1960s increased the success rate of ESRD treatment, and it prolonged the life span of the patients. The rise in the number haemodialysis patients and prolonged longevity became a concern for clinicians on complications stemming from vascular access. Upper extremity complications throughout the course of time beginning with haemodialysis developing regardless of the area and type of vascular intervention were established by studies. These complications include peripheral nerve entrapment neuropathies, avoidance of using the extremity having the vascular access, edema occurring in the upper extremity due vascular insufficiency, swelling, sweating issues, and insufficiency in upper extremity functions [1].

In addition to vascular access related complications in haemodialysis patients, abnormal electrolyte levels due to disorder in renal functions and tissue damage developing due to metabolic condition may cause musculoskeletal system and neurologic dysfunctions in the upper extremities. Such dysfunctions comprise myasthenia and sensory disorders [2].

In literature, there exist studies that investigate hand functions in HD patients and put forth dysfunctions in the established results [3-5]. However, it has yet to be possible to distinguish whether the upper extremity and hand dysfunctions observed in HD patients stem from amyloidosis caused by the disease or from vascular interventions generally on upper extremities and resulting complications. The objective of this pilot study is to evaluate the hand functions of patients receiving HD treatment through arteriovenous fistula, comparison with healthy individuals, and to establish whether the functional disorders result from complications developing due to amyloidosis or vascular interventions.

\section{METHODS}

Protocol of this study was approved by the decision number 2012-328 by the Clinical Studies Ethics Committee of Gazi University Medical School.

\section{Participants}

The patient group of this study $(n=15)$ was comprised of patients being followed up and receiving haemodialysis treatment at the Department of $\mathrm{Ne}$ phrology in Gazi University Medical School Hospital, and the control group $(n=11)$ contained healthy volunteers from same age interval with the patient group. Inclusion criteria for the patient group were being diagnosed with ESRD by a nephrologist and being 18 years of age or older. Participants that previously had upper extremity malformation, inflammatory arthritis and/or any upper extremity surgery were excluded from the study. Informed consents of the entire participants were obtained following information on the study was provided.

\section{Study Protocol}

Such demographic information of the entire participants as age, height, weight, and gender and the duration of haemodialysis treatment were investigated. Also recorded were their dominant hands, whether they previously had renal transplantation, family histories, and the presence of any deformities or complications in upper extremities (carpal tunnel syndrome, Dupuytren's Contracture, etc.).

Evaluation of the functional conditions of each group was carried out by using grip strength, pinching strength, and 9-hole peg test [6]. Digital dynamometer was used to assess the grip strength, and 3 separate pinching strengths (bipod, tripod and lateral pinch) were evaluated by pinchmeter. Measurements were conducted with participants sitting on a chair with back support, shoulders adducted, elbows at 90 degrees flexion, and forearms in neutral position, and each measurements were repeated 3 times and average results were recorded [7]. All the measurements were carried out by the same researcher and for both hands. Values were recorded in kilogram-force (kg-f). Nine-hole peg test was evaluated by recording timed performances of removal and replacement functions [6]. Tests were conducted before the treatment sessions for each patient receiving $\mathrm{HD}$ treatment.

Disability levels of patients were evaluated with DASH-T (Turkish version of the Disability of Shoul- 
der, Elbow and Hand (DASH) questionnaire) [8] questionnaire. DASH-T is a valid and reliable selfevaluation result measurement questionnaire that assesses physical disability and symptoms in various upper extremity disorders [9]. From this questionnaire comprised of questions evaluating difficulties in activities, symptoms, social functions, occupation, sleep, and self-confidence of the patient, and issues with work and hobbies, a result between 0 and 100 is obtained $(0=$ no disability, $100=$ maximum disability).

\section{Statistical Analysis}

Test results were represented as mean plus/minus standard deviation and statistical analyses were carried out by using SPSS Version 15.0. For the comparison of results of patients receiving haemodialysis treatment with the results of healthy control group members, Mann-Whitney U test was used.

\section{RESULTS}

Demographic data of the patient and control groups are summarized in Table 1. Mean age of patient and control groups were similar ( $p>0.05)$.

Arteriovenous fistula was located in the dominant extremity in 3 patients and in the non-dominant extremity in 12 patients in the patient group. None of the patients had renal transplantation and family history. Besides, no deformity and/or complication were established in upper extremities.

Table 2 demonstrates grip, lateral, bipod and tripod pinch strengths of groups. When an intergroup comparison was conducted, all results of the patient group excluding the right hand lateral pinch were found as significantly lower than the control group $(p<0.05)$. In in-group comparisons, a significant difference was not established between right and left hand in both groups $(p>0.05)$ (Table 3$)$.
While a significant difference was established when compared the functional level of the hand between the groups $(p<0.01)$, similar results were obtained in both extremities in in-group comparisons ( $p>0.05)$ (Table 4).

Results of DASH questionnaire that determines disability levels of upper extremities of the patient group were established as mean 53,28 ; this score was observed as corresponding to "medium" disability level.

Table 1. Demographic data of the patient and control groups

\begin{tabular}{lcc}
\hline & $\begin{array}{c}\text { Patients } \\
(\mathbf{n}=15)\end{array}$ & $\begin{array}{c}\text { Controls } \\
(\mathbf{n}=11)\end{array}$ \\
\hline Age (years) & $57 \pm 15$ & $54 \pm 10$ \\
Gender & $4 \mathrm{~F}, 11 \mathrm{M}$ & $2 \mathrm{~F}, 9 \mathrm{M}$ \\
Mean HD duration (months) & 49 & \\
\hline
\end{tabular}

HD: hemodialysis

Table 2. Comparison of grip, lateral, bipod and tripod pinch strengths between the groups $\left({ }^{*}: p<0.05\right)$

\begin{tabular}{lccc}
\hline & & $\begin{array}{c}\text { Patients } \\
(\mathbf{n}=15)\end{array}$ & $\begin{array}{c}\text { Controls } \\
(\mathbf{n}=11)\end{array}$ \\
\hline Grip (kg) & $\mathrm{R}$ & $24 \pm 11$ & $37 \pm 10^{*}$ \\
& $\mathrm{~L}$ & $21 \pm 10$ & $34 \pm 7^{*}$ \\
Lateral pinch (kg) & $\mathrm{R}$ & $7 \pm 2$ & $10 \pm 1$ \\
& $\mathrm{~L}$ & $6 \pm 3$ & $9 \pm 1^{*}$ \\
Bipod pinch (kg) & $\mathrm{R}$ & $4 \pm 2$ & $6 \pm 1^{*}$ \\
& $\mathrm{~L}$ & $4 \pm 2$ & $6 \pm 1^{*}$ \\
Tripod pinch (kg) & $\mathrm{R}$ & $3 \pm 3$ & $8 \pm 1^{*}$ \\
& $\mathrm{~L}$ & $3 \pm 3$ & $7 \pm 1^{*}$ \\
\hline
\end{tabular}

R: right, L: left

Table 3. Comparison of grip, lateral, bipod, and tripod pinch strengths of the groups within themselves $(p>0.05)$

\begin{tabular}{lcccccccc}
\hline & \multicolumn{2}{c}{ Grip $\mathbf{( k g )}$} & \multicolumn{2}{c}{ Lateral pinch $(\mathbf{k g})$} & \multicolumn{2}{c}{ Bipod pinch $(\mathbf{k g})$} & \multicolumn{2}{c}{ Tripod pinch $(\mathbf{k g})$} \\
\cline { 2 - 8 } & Patients & Controls & Patients & Controls & Patients & Controls & Patients & Controls \\
\hline Right & $24 \pm 11$ & $37 \pm 10$ & $7 \pm 2$ & $10 \pm 1$ & $4 \pm 2$ & $6 \pm 1$ & $3 \pm 3$ & $8 \pm 1$ \\
Left & $21 \pm 10$ & $34 \pm 7$ & $6 \pm 3$ & $9 \pm 1$ & $4 \pm 2$ & $6 \pm 1$ & $3 \pm 3$ & $7 \pm 1$ \\
\hline
\end{tabular}


Table 4. Nine-hole peg test results of the groups

\begin{tabular}{llcc}
\hline & & Patients & Controls \\
\hline \multirow{2}{*}{ Right } & Replacement (sec) & $20 \pm 9$ & $7 \pm 1^{*}$ \\
& Removal (sec) & $19 \pm 8$ & $8 \pm 1^{*}$ \\
\multirow{2}{*}{ Left } & Replacement (sec) & $12 \pm 1$ & $12 \pm 2^{*}$ \\
& Removal (sec) & $5 \pm 1$ & $6 \pm 1^{*}$ \\
\hline
\end{tabular}

$\left({ }^{*} p<0.01\right)$

\section{DISCUSSION}

This study established that the functional use of the hand decreased in ESRD patients receiving HD treatment through arteriovenous fistula placed in the upper extremity. In almost all the results of gripping and pinching strength measurements, and speed tests, with which we evaluated the functional condition of the hand, the performance of both extremities of HD patients were found as low compared to the control group. However, in-group comparison of both hands showed no significant differences regarding hand functions.

In ESRD, chronic renal dysfunction is generally accompanied by fluid-electrolyte imbalance and toxic metabolites. Tissue damage due to such abnormal electrolyte levels and metabolic condition may cause musculoskeletal system disorders and neurologic disorders [1]. These disorders include muscle weakness and abnormal sensory function [2]. Parallel to all these studies, it was established that the physical performances of dialysis patients were lower and their disability levels in daily life activities were higher compared to healthy groups within the same age range $[10,11]$.When compared with healthy cases in our study, similar to numerous previous studies, hand functions of both extremities of HD patients were found to decrease. This result also reflected itself in disability level evaluations of HD patients included in our study. Based on DASH questionnaire that evaluate the disability level through bilateral activities of upper extremities, disability levels of the patients were found to be medium level.

In a cross-sectional study conducted in 2012 , upper extremity muscle strength and shoulder movements of HD patients with arteriovenous fistula or graft were demonstrated as inferior compared to the control group comprised of healthy individuals. The same study also found that complications related with upper extremities were more significant in the extremity having fistula [12]. Contrary to this, in a recent study by Soyupek et al., upper extrem- ity complication prevalence was found as similar in dialysis patients receiving treatment by HD method and peritoneal dialysis patients without vascular access [13]. Such a contradiction between the results obtained from different studies also appeared in our study as the most significant result. Parallel to the result obtained by Soyupek et al. in their study, this outcome shows itself as the similarity between the scores of gripping functions of both hands and 9-hole peg test scores in patients receiving HD treatment. We believe that the said contradiction in study results were related to the variable assessing tools. In a study conducted by Capitani et al., only the differences in strength and range of motion were evaluated while conducting assessments concerning upper extremities [12]. Our evaluations were more towards methods assessing upper extremity functionality. The contribution of strength and range of motion to function is by all means indisputable. However, a person may complete the function by enabling certain compensation mechanisms even though strength and range of motion is missing while conducting the said function. Functional assessment is highly correlated with the quality of life and independence levels in daily life instead of examining the physical fitness sub-parameters one by one. Indifference between two extremities in terms of hand functions led us to believe that upper extremity dysfunction stems from the nature of the disease or from HD treatment rather than vascular access.

In a recent study by Soyupek et al., upper extremity complication prevalence was found as similar in both HD and peritoneal dialysis patients [13] This result supports the conclusion of our study and brings forth the opinion that hand dysfunction may be correlated with the nature of the disease.

Despite the fact that the number of participants in our study was lower stood out as an important limitation, significant results were obtained even in a smaller population. Use of computer-assisted equipment instead of digital dynamometer we utilized may enable the analysis of more statistical data. In addition, our study was conducted on HD patients with arteriovenous fistula due to the fact that its objective was to evaluate upper extremity functions. Evaluation of patients receiving HD treatment via catheterisation and patients receiving peritoneal dialysis treatment as well may shed light to the question as to whether the outcome result from $\mathrm{HD}$ or from the disease itself.

Consequently, functional levels of the hand is reduced in patients receiving HD treatment via arte- 
riovenous fistula in upper extremity and that such a reduction was observed to be independent from the treatment. It is believed that rehabilitation approaches towards increasing the functional use of the hand may prove to be beneficial in the routine treatment program of end stage renal failure patients.

Conflict of Interest: On behalf of all authors, the corresponding author states that there is no conflict of interest.

\section{REFERENCES}

1. Hurton S, Embil JM, Reda A. et al. Upper extremity complications in patients with chronic renal failure receiving haemodialysis. J Renal Care 2010;36:203211.

2. Calik BB, Yagci N, Cavlak U. Upper extremities function in patients undergoing haemodialysis treatment. Neurosciences 2006;11:180-186.

3. Hsieh RL, Huang HY, Chen SC, et al. Changes in physical functional performance and quality of life in hemodialysis patients in Taiwan: a preliminary study. J Nephrol 2010;23:41-48.

4. Tander B, Akpolat T, Durmus D, Canturk F. Evaluation of hand functions in hemodialysis patients. Renal Failure 2007;29:477-480.

5. V Limaye, A Frankham, A Disney, K Pile. Evaluation of hand function in patients undergoing long term haemodialysis. Ann Rheum Dis 2001;60:278-280.
6. Oxford Grice K, Vogel KA, Le V, et al. Adult norms for a commercially available Nine Hole Peg Test for finger dexterity. Am J Occup Ther 2003;57:570-573.

7. Mathiowetz V, Weber K, Volland G, Kashman N. Reliability and validity of grip and pinch strength evaluations. J Hand Surg Am 1984;9:222-226.

8. Düger T, Yakut E, Öksüz Ç, et al. Kol, Omuz ve El Sorunları (Disabilities of the Arm, Shoulder and Hand - DASH) Anketi Türkçe uyarlamasının güvenirliği ve geçerliği. Fizyoter Rehabil. 2006;17:99-107.

9. Azboy I, Demirtaş A, Alemdar C, et al. The outcomes of volar locking plating for intraarticular distal radius fractures. Dicle Med J 2014;41:282-287.

10. Cook WL, Jassal SV. Functional dependencies among the elderly on hemodialysis. Kidney Int 2008;73:12891295.

11. Altintepe L, Levendoglu F, Okudan N, et al. Physical disability, psychological status, and health-related quality of life in older hemodialysis patients and agematched controls. Hemodialysis Int 2006;10:260-266.

12. Capitanini A, Galligani C, Lange S, Cupisti A. Upper limb disability in hemodialysis patients: evaluation of contributing factors aside from amyloidosis. Ther Apher Dial 2012;16:242-247.

13. Soyupek F, Demir M, Süslü FE, et al. The upper extremity musculoskeletal complications in dialysis patients: comparison between hemodialysis and peritoneal dialysis.J Back Musculoskelet Rehabil 2013;26:267-371. 